\title{
Mapping of Quantitative Trait Loci Controlling Egg-Quality and -Production Traits in Japanese Quail (Coturnix japonica) Using Restriction-Site Associated DNA Sequencing
}

\author{
Mohammad Ibrahim Haqani ${ }^{1, *(\mathbb{D})}$, Shigeru Nomura ${ }^{1}$, Michiharu Nakano ${ }^{1} \mathbb{D}$, Tatsuhiko Goto ${ }^{2,3}$ (D), $^{\mathbb{2}}$ \\ Atsushi J. Nagano ${ }^{4}$, Atsushi Takenouchi ${ }^{1,3}$, Yoshiaki Nakamura 1,3 ${ }^{\mathbb{D}}$, Akira Ishikawa ${ }^{3,5, *}$ \\ and Masaoki Tsudzuki 1,3,*(D) \\ 1 Graduate School of Integrated Sciences for Life, Hiroshima University, Higashi-Hiroshima, \\ Hiroshima 739-8525, Japan; m190772@hiroshima-u.ac.jp (S.N.); minaka@hiroshima-u.ac.jp (M.N.); \\ takeatsu@hiroshima-u.ac.jp (A.T.); ynsu@hiroshima-u.ac.jp (Y.N.) \\ 2 Research Center for Global Agromedicine, Obihiro University of Agriculture and Veterinary Medicine, \\ Obihiro, Hokkaido 080-8555, Japan; tats.goto@obihiro.ac.jp \\ 3 Japanese Avian Bioresource Project Research Center, Hiroshima University, Higashi-Hiroshima, \\ Hiroshima 739-8525, Japan \\ 4 Faculty of Agriculture, Ryukoku University, Otsu, Shiga 520-2194, Japan; anagano1234@gmail.com \\ 5 Graduate School of Bioagricultural Sciences, Nagoya University, Nagoya, Aichi 464-8601, Japan \\ * Correspondence: enghaqani@gmail.com (M.I.H.); ishikawa@agr.nagoya-u.ac.jp (A.I.); \\ tsudzuki@hiroshima-u.ac.jp (M.T.); Tel./Fax: +81-82-424-7950 (M.I.H. \& M.T.); +81-52-789-4101 (A.I.)
}

Citation: Haqani, M.I.; Nomura, S. Nakano, M.; Goto, T.; Nagano, A.J.; Takenouchi, A.; Nakamura, Y.; Ishikawa, A.; Tsudzuki, M. Mapping of Quantitative Trait Loci Controlling Egg-Quality and -Production Traits in Japanese Quail (Coturnix japonica) Using Restriction-Site Associated DNA Sequencing. Genes 2021, 12, 735. https://doi.org/10.3390/ genes12050735

Academic Editor: Brynn H. Voy

Received: 22 March 2021

Accepted: 8 May 2021

Published: 13 May 2021

Publisher's Note: MDPI stays neutral with regard to jurisdictional claims in published maps and institutional affiliations.

Copyright: (C) 2021 by the authors. Licensee MDPI, Basel, Switzerland. This article is an open access article distributed under the terms and conditions of the Creative Commons Attribution (CC BY) license (https:// creativecommons.org/licenses/by/ $4.0 /)$.

\begin{abstract}
This research was conducted to identify quantitative trait loci (QTL) associated with eggrelated traits by constructing a genetic linkage map based on single nucleotide polymorphism (SNP) markers using restriction-site associated DNA sequencing (RAD-seq) in Japanese quail. A total of $138 \mathrm{~F}_{2}$ females were produced by full-sib mating of $\mathrm{F}_{1}$ birds derived from an intercross between a male of the large-sized strain with three females of the normal-sized strain. Eggs were investigated at two different stages: the beginning stage of egg-laying and at 12 weeks of age (second stage). Five eggs were analyzed for egg weight, lengths of the long and short axes, egg shell strength and weight, yolk weight and diameter, albumen weight, egg equator thickness, and yolk color ( $L^{*}, a^{*}$, and $b^{*}$ values) at each stage. Moreover, the age at first egg, the cumulative number of eggs laid, and egg production rate were recorded. RAD-seq developed 118 SNP markers and mapped them to 13 linkage groups using the Map Manager QTX b20 software. Markers were spanned on $776.1 \mathrm{cM}$ with an average spacing of $7.4 \mathrm{cM}$. Nine QTL were identified on chromosomes 2, 4, 6, 10, 12, and Z using the simple interval mapping method in the R/qtl package. The QTL detected affected $10 \mathrm{egg}$ traits of egg weight, lengths of the long and short axes of egg, egg shell strength, yolk diameter and weight, albumen weight, and egg shell weight at the beginning stage, yellowness of the yolk color at the second stage, and age at first egg. This is the first report to perform a quail QTL analysis of eggrelated traits using RAD-seq. These results highlight the effectiveness of RAD-seq associated with targeted QTL and the application of marker-assisted selection in the poultry industry, particularly in the Japanese quail.
\end{abstract}

Keywords: egg-related traits; QTL; RAD-seq; SNP marker; Japanese quail

\section{Introduction}

Tremendous progress has been made in poultry egg production and breeding programs over the past decades, leading to the fast-growing livestock industry. In the future, increased advances are required to enhance egg-quality traits in particular. Egg-related traits are complex traits controlled by multiple quantitative trait loci (QTL) and are influenced by genetic and environmental factors and their interactions [1]. QTL analysis can 
increase the selection response in breeding programs by investigating genotype and phenotype relationships using marker-assisted selection (MAS) [2,3]. Several DNA markers, such as single nucleotide polymorphisms (SNPs) [4], restriction fragment length polymorphisms [5], amplified fragment length polymorphisms (AFLPs) [6], and simple sequence length polymorphisms (or microsatellite) [7], have been used to identify the chromosomal positions of loci. Among these markers, SNPs play a crucial role in genetics, biomedicine, ecology, and evolutionary studies [8-11]. The other types of DNA markers are associated with a limited number of available markers, high cost of genotyping, and relatively large distance between marker and QTL [12]. In contrast, SNP markers show a stably inherited mechanism, provide more potential markers near or in any locus of interest, are located in coding regions, directly affect protein function, and are more suitable for throughput genetic analysis [13]. It has been difficult to obtain increased markers in the last few years owing to labor and cost-intensive approaches [14]. Next-generation sequencing technologies with recent advances in genotyping by sequencing (GBS) methods and related bioinformatics-computing resources facilitate the large-scale, rapid, and cost-effective discovery of SNPs [15-19]. Restriction-site associated DNA sequencing (RAD-seq) is a GBS method that can simultaneously identify, verify, and score thousands of SNPs, reduce complexity across genomes, deliver high-resolution population genomic data, and be convenient for non-model species at a reasonable cost [20-23].

The Japanese quail (Coturnix japonica), similar to chicken, belongs to the order Galliformes and the family phasianidae, is a model bird used for production [24] and experimental purposes $[25,26]$. The Japanese quail as an oviparous animal has a small body size, shows a rapid turnover of generations, has inexpensive rearing requirements, is adaptable to a wide range of husbandry conditions, is easy to handle, has fast growth performance, shows resistance to diseases, and is a more efficient converter of feed to eggs than chickens and can lay approximately 300 eggs per year $[27,28]$.

Quail eggs are a suitable source of animal protein and fulfill the nutritional requirements of the growing world population. These eggs contain all essential amino acids for humans and provide a sufficient amount of several vitamins and minerals. External and internal egg-related traits are the most important egg traits that influence egg quality, hatching performance, body weight of newly hatched chicks, propagation of flocks, and breeding economy of the poultry industry [29]. These factors highlight the importance of egg quality in modern poultry breeding conditions. In the current study, we used large-sized (LS) and normal-sized (NS) Japanese quail strains as parents to develop an $\mathrm{F}_{2}$ resource population. The LS Japanese quail has a large body weight and is used for meat production purposes. NS Japanese quails have a normal body weight and are used for egg production [30].

Compared with chickens, few studies have performed QTL analysis on the Japanese quail, and the genome of this species has been poorly explored [31]. The first studies reported on the genetic and QTL analyses of the Japanese quail involved the identification of panels of markers [32,33], construction of genetic maps using AFLP [34] and microsatellite [35], complete sequencing of the mitochondrial genome [36], detection of QTL for growth-performance and meat-quality traits [37], determination of egg-laying curve [38], and analyses of carcass traits, internal organs [39], and fearfulness-related traits [6,40]. The construction of genetic maps and QTL analysis in poultry have mostly focused on chickens rather than Japanese quails. Recently, existing reports on the genetic map of the Japanese quail were integrated and aligned to the assembled chicken sequence data [41]. As the Japanese quail shows close phylogenetic relatedness to chickens with similar length of the genome $\left(1.2 \times 10^{9}\right.$ base pairs $)$ and chromosome number $(2 n=78)$ and homology of chromosome morphology, a high rate of synteny conservation is expected between the two species [42]. According to the chicken QTL database (QTLdb) [43], 11,818 QTL responsible for 420 different traits have been detected in 318 studies [44-50]. On the contrary, few studies have reported the QTL responsible for egg-related traits in the Japanese quail. Knaga et al. [31] revealed four QTL on chromosome 1 that affect egg number, egg production 
rate, egg weight, and egg shell weight. Recoquillay et al. [51] found four QTL for the mean egg weight located on chromosomes 1,3, and 18, two QTL for the number of eggs laid positioned on chromosomes 3 and 18, and two QTL for the age at first egg placed on chromosomes 3 and 19 in a study of medium-density genetic map and QTL analyses of the Japanese quail, in which egg weight as an egg-quality trait and two egg production traits were investigated. Minvielle et al. [52] identified QTL for egg weight, egg number, and age at first egg on chromosome 6 and eggshell weight on chromosomes 1, 5, and 20 using microsatellite markers.

Next-generation sequencing [53] and the construction of high-resolution linkage maps based on SNP markers have been performed in the Japanese quail [6,51]. To the best of our knowledge, there are no published reports on QTL analysis of egg-related traits using RAD-seq in the Japanese quail. However, genetic analysis studies using the RAD-seq method in chickens [54,55], aquaculture [56-58], and mammals $[59,60]$ have been reported previously. Hence, the aim of this study was to detect QTL affecting egg-quality and -production traits by constructing a genetic linkage map based on SNP markers using RAD-seq in the Japanese quail.

\section{Materials and Methods}

\subsection{Experimental Birds}

LS and NS quail strains were reared at the Research Farm of Hiroshima University, Japan. $F_{1}$ birds were obtained from an intercross of one LS male with three NS females. Subsequently, $138 \mathrm{~F}_{2}$ females were produced from an intercross between three $\mathrm{F}_{1}$ males and nine $F_{1}$ females. In addition to the above three parents and nine $F_{1}$ females, the phenotypic values of 97 parents and $16 \mathrm{~F}_{1}$ females were used for comparison. Chick management and food supply were in accordance with a previous study [61]. Newly hatched chicks were leg-banded and weighed before being moved to heated brooders, where they were reared until 4 weeks of age. Thereafter, they were housed in individual cages (depth: $15 \mathrm{~cm}$; width: $18 \mathrm{~cm}$; height: $18 \mathrm{~cm})$. Chicks were fed a standard chick diet $(22 \%$ crude protein (CP); $2900 \mathrm{kcal}$ metabolizable energy (ME) $\mathrm{kg}^{-1}$ ) ad libitum for ages 0 to 4 weeks, followed by a grower diet $\left(17 \% \mathrm{CP}\right.$ and $\left.2850 \mathrm{kcal} \mathrm{ME} \mathrm{kg}^{-1}\right)$ from 4 to 16 weeks of age. The birds were maintained under a 24-h lighting photoperiod for 4 weeks, followed by a $14 \mathrm{~h}: 10 \mathrm{~h}$ light:dark cycle. They were reared according to the protocol described in the Guidelines for Proper Conduct of Animal Experiments [62].

\subsection{Traits}

A total of 263 female quails were used to assess egg-related traits. Blood samples from all birds were collected using the method described by Kabir et al. [63]. External and internal egg-related traits were measured at two different egg production stages, at the beginning of the egg production period (first stage) and 12 weeks of age (second stage). The two stages are indicated with the subscript letters ${ }_{1}$ and 2 in the abbreviations of traits. Five eggs from each quail hen were evaluated at each stage. In general, a total number of 2630 eggs were measured from the parental, $F_{1}$, and $F_{2}$ generations. A total of 1000,250 and 1380 eggs were evaluated at the parental, $\mathrm{F}_{1}$, and $\mathrm{F}_{2}$ generations, respectively. External and internal egg-related traits, including egg weight (EW), egg long axis (ELA), egg short axis (ESA), egg shell strength (ESS), egg shell weight (ESW), egg equator thickness (EET), yolk weight $(\mathrm{YW})$, yolk diameter (YD), yolk color, lightness ( $\mathrm{L}^{*}$ value) $\left(\mathrm{YC}-\mathrm{L}^{*}\right)$, redness $\left(\mathrm{a}^{*}\right.$ value) (YC-a*), and yellowness ( $b^{*}$ value) $\left(Y C-b^{*}\right)$, and albumen weight $(A W)$, as well as the age at first egg (AFE), total number of laid eggs from maturation up to 16 weeks of age (TLE), and egg production rate (EPR) were used for evaluation in this study. 
EW, ESW, YW, and AW were measured using a digital balance GX-2000 (A \& D Company Ltd., Tokyo, Japan). The lengths of ELA and ESA, and YD were measured using a digital micrometer ABS Digi-Kanon (Nakamura Mfg. Co. Ltd., Tokyo, Japan). For the ESS, an egg shell strength meter (FHK Fujihira Industry Co. Ltd., Tokyo, Japan) was used. EST was measured using an eggshell thickness micrometer (Mitutoyo Industry Co. Ltd., Tokyo, Japan). Yolk color results were obtained using the international colorimetric system of CIELAB. The calibration was based on a black standard with $L^{*}=0$ and a white standard with $L^{*}=100$. The balanced CIELAB system was determined by three mutually perpendicular axes $L^{*}, a^{*}$, and $b^{*}$ defined by lightness, redness, and yellowness of yolk color, respectively. The coordinates $a^{*}$ and $b^{*}$ represent the regions of the spectrum with wavelengths corresponding to colors from green $(-a)$ to red $(+a)$ and from blue $(-b)$ to yellow $(+b)$, respectively. The scale of lightness $L^{*}$ represents an interval from 0 (black) to 100 (white). Thus, the complementary color system was based on the differences in the three elementary color pairs: red/green, yellow/blue, and black/white [64,65]. A Chroma meter CR-300 was used to measure the YC-L*, $\mathrm{a}^{*}$, and $\mathrm{b}^{*}$ values (Konica Minolta Holdings Inc., Tokyo, Japan).

\subsection{RAD Library Preparation and Sequencing}

Collected blood samples from all birds were used for the extraction of genomic DNA using the phenol-chloroform method and Qiagen kit (DNeasy Blood \& Tissue KitsQIAGEN, Venlo, The Netherlands), according to the manufacturer's protocol. The quality of extracted DNA in each sample was measured using a Qubit 3.0 assay fluorometer (Thermo Fisher Scientific Inc. Waltham, MA, USA), and the DNA was finally adjusted to a concentration of $20 \mathrm{ng} / \mu \mathrm{L}$ for RAD-seq. RAD-seq was performed for the 4 parents and $12 \mathrm{~F}_{1}$ and $138 \mathrm{~F}_{2}$ individuals. The RAD library construction procedure followed the methodology previously described by Sakaguchi et al. [66]. The RAD library was sequenced using HiSeq 2500 (Illumina, San Diego, CA, USA) in a 50-bp single-end adapter using EcoRI and BglII. The RAD-seq read data were consigned in the DDBJ Sequence Read Archive (accession no. DRA011153). The RAD-seq reads were trimmed using the Trim_Galore program (http:/ / www.bioinformatics.babraham.ac.uk/projects/trim_galore/, accessed on 16 March 2020), and the trimmed reads were mapped onto the Japanese quail genome (GCA_001577835.1 Coturnix japonica 2.-NCBI) using Bowtie2 [67]. The resulting binary sequence alignment/map format (BAM) files processed with SAMtools [68] were used for variant detection. Variant detection was initially performed for $F_{1}$ strains. The BAM files of $F_{1}$ strains were processed using SAMtools mpileup and varscan2 mpileup2cns [69] with default parameters but changed to min-coverage 5 . The variant call format (vcf) files were merged with bcftools [70], and the merged vcf file was further screened using vcftools [71] with the following parameters: minDP 5, min-meanDP 5, maxDP 100, minalleles 2, and max-alleles 2 . The screened sites, which were heterozygous for all $\mathrm{F}_{1}$ strains, were summarized in the position list. With the position list, polymorphisms of all samples, including strains of $\mathrm{P}_{1}, \mathrm{P}_{2}, \mathrm{~F}_{1}$, and $\mathrm{F}_{2}$, were called using samtools mpileup and varscan with the above parameters and merged using bcftools. After the polymorphism detection steps, only the GT fields were exported using vcftools and used for further analysis.

The RAD-seq reads that showed different alleles between the two parental strains and genotyped in more than $90 \%$ of the $\mathrm{F}_{2}$ resource population were selected for mapping. The Map Manager QTX b20 application was used to construct the linkage map [72]. The Kosambi map function was used to calculate the genetic distance with linkage criterion $p=0.001$ [73].

\subsection{QTL Analysis}

The scanone function of R/qtl [74] was used for QTL analysis using the simple interval mapping method [75]. The genome-wide significance (1\% and 5\%) and suggestive at $(10 \%)$ threshold levels were determined by 1000 permutation tests [76]. The significant thresholds for the $\mathrm{Z}$ chromosome were estimated using the method described by Broman 
et al. [77]. The confidence interval from the logarithm of odds (LOD) drop-off method was calculated as 1.8 in this study [78]. The statistical analysis for the calculation of confidence interval, percentage of phenotypic variance, and additive and dominant effects of QTL was conducted using R/qtl based on a previous study [76].

\subsection{Statistical Analysis}

Egg-related data were adjusted for the effects of birth date and dams using the least squares method in R-Project for Statistical Analysis v. 3.6.1. [79]. Egg-related trait comparisons among parental, $\mathrm{F}_{1}$, and $\mathrm{F}_{2}$ generations were performed using one-way analysis of variance (ANOVA), followed by Tukey's HSD test with JMP v. 11.0.2 (SAS Institute Inc., Tokyo, Japan).

\section{Results}

\subsection{Phenotypic Values}

The estimated means and standard errors for egg-related traits are shown in Table 1. The LS birds presented the highest values for $\mathrm{EW}_{1}, \mathrm{ELA}_{1}, \mathrm{ESA}_{1}, \mathrm{AW}_{1}, \mathrm{YW}_{1}, \mathrm{ESW}_{1}, \mathrm{EW}_{2}$, $\mathrm{ESA}_{2}, \mathrm{AW}_{2}$, and $\mathrm{ESW}_{2}$ traits. Significant differences were observed for the $\mathrm{YC}-\mathrm{a}^{*}{ }_{1}$ and $\mathrm{ESA}_{2}$ traits between each generation. The highest values were detected for $\mathrm{YC}^{-\mathrm{a}^{*}}{ }_{1}$ in NS, both stages of $Y C-L^{*}$ in $F_{1}$, and $Y C-b^{*} 1, \mathrm{YD}_{2}$, and AFE in the $\mathrm{F}_{2}$ generation. On the contrary, the lowest values of $\mathrm{ESA}_{2}, \mathrm{YD}_{2}$, and $\mathrm{YW}_{2}$ for $\mathrm{NS}$ and $\mathrm{YC}-\mathrm{a}^{*}$ in both stages and $\mathrm{ESS}_{2}$ for $\mathrm{F}_{2}$ generation were observed. No significant difference was observed between the parents and the $\mathrm{F}_{1}$ generation for $\mathrm{ESA}_{2}$, TLE, and EPR. In addition, no significant difference was observed for $\mathrm{EW}_{1}, \mathrm{ELA}_{1}, \mathrm{ESA}_{1}$, and $\mathrm{YW}_{1}$ between the NS and both filial generations.

Table 1. Egg-related traits (mean \pm standard error) used in this study.

\begin{tabular}{|c|c|c|c|c|}
\hline Traits & LS $(n=50)$ & NS $(n=50)$ & $\mathrm{F}_{1}(n=25)$ & $\mathrm{F}_{2}(n=138)$ \\
\hline Egg weight $_{1}(\mathrm{~g})$ & $10.065 \pm 0.113^{a}$ & $8.508 \pm 0.107^{b}$ & $9.001 \pm 0.1715^{b}$ & $8.616 \pm 0.0771^{b}$ \\
\hline Egg long axis $1(\mathrm{~mm})$ & $30.767 \pm 0.144^{\mathrm{a}}$ & $29.990 \pm 0.185^{b}$ & $29.803 \pm 0.2095^{b}$ & $29.754 \pm 0.1052^{b}$ \\
\hline Egg short axis $_{1}(\mathrm{~mm})$ & $24.754 \pm 0.094^{\mathrm{a}}$ & $23.497 \pm 0.097^{b}$ & $23.746 \pm 0.1295^{b}$ & $23.460 \pm 0.0687^{b}$ \\
\hline Egg shell strength $1\left(\mathrm{~kg} / \mathrm{cm}^{2}\right)$ & $1.392 \pm 0.037^{b}$ & $1.519 \pm 0.041^{\mathrm{a}}$ & $1.446 \pm 0.0319 \mathrm{ab}$ & $1.219 \pm 0.0160^{c}$ \\
\hline Yolk diameter $_{1}(\mathrm{~mm})$ & $23.783 \pm 0.148^{a}$ & $23.132 \pm 0.206^{b}$ & $23.107 \pm 0.1925^{b}$ & $23.983 \pm 0.1003^{a}$ \\
\hline Albumen weight $_{1}(\mathrm{~g})$ & $5.482 \pm 0.067^{\mathrm{a}}$ & $4.511 \pm 0.057^{\mathrm{c}}$ & $4.914 \pm 0.0852^{b}$ & $4.664 \pm 0.0430 \mathrm{bc}$ \\
\hline Yolk weight $_{1}(\mathrm{~g})$ & $3.082 \pm 0.048^{\mathrm{a}}$ & $2.900 \pm 0.051^{b}$ & $2.829 \pm 0.0531^{b}$ & $2.843 \pm 0.0291^{b}$ \\
\hline Egg shell weight $_{1}(\mathrm{~g})$ & $1.166 \pm 0.013^{\mathrm{a}}$ & $1.023 \pm 0.014^{b c}$ & $1.081 \pm 0.0211^{b}$ & $0.979 \pm 0.0099^{c}$ \\
\hline Egg equator thickness $_{1}(\mathrm{~mm})$ & $0.283 \pm 0.003^{a b}$ & $0.279 \pm 0.003^{b}$ & $0.293 \pm 0.0025^{\mathrm{a}}$ & $0.285 \pm 0.0016^{\mathrm{ab}}$ \\
\hline Yolk color-lightness $_{1}$ & $56.234 \pm 0.219^{b}$ & $56.506 \pm 0.293^{b}$ & $58.317 \pm 0.3500^{\mathrm{a}}$ & $55.782 \pm 0.1431^{b}$ \\
\hline Yolk color-redness 1 & $9.068 \pm 0.268^{b}$ & $10.531 \pm 0.348^{\mathrm{a}}$ & $5.327 \pm 0.5274^{c}$ & $2.636 \pm 0.2340^{\mathrm{d}}$ \\
\hline Yolk color-yellowness 1 & $36.519 \pm 0.341^{b}$ & $36.252 \pm 0.365^{b}$ & $34.338 \pm 0.3670^{\mathrm{c}}$ & $38.252 \pm 0.2120^{\mathrm{a}}$ \\
\hline Egg weight $_{2}(\mathrm{~g})$ & $12.152 \pm 0.124^{\mathrm{a}}$ & $9.905 \pm 0.116^{\mathrm{c}}$ & $10.846 \pm 0.168^{b}$ & $10.059 \pm 0.100^{\mathrm{c}}$ \\
\hline Egg long axis $2(\mathrm{~mm})$ & $31.958 \pm 0.136^{a b}$ & $31.442 \pm 0.175^{b}$ & $31.665 \pm 0.187^{a b}$ & $32.045 \pm 0.116^{\mathrm{a}}$ \\
\hline Egg short axis $2(\mathrm{~mm})$ & $26.175 \pm 0.104^{\mathrm{a}}$ & $24.087 \pm 0.095^{\mathrm{d}}$ & $25.181 \pm 0.170^{\mathrm{b}}$ & $24.566 \pm 0.077^{\mathrm{c}}$ \\
\hline Egg shell strength $\left(\mathrm{kg} / \mathrm{cm}^{2}\right)$ & $1.479 \pm 0.053^{\mathrm{a}}$ & $1.523 \pm 0.049^{\mathrm{a}}$ & $1.480 \pm 0.040^{\mathrm{a}}$ & $1.209 \pm 0.014^{\mathrm{b}}$ \\
\hline Yolk diameter $2(\mathrm{~mm})$ & $25.164 \pm 0.126^{b}$ & $23.650 \pm 0.154^{\mathrm{c}}$ & $24.985 \pm 0.164^{b}$ & $26.135 \pm 0.109^{a}$ \\
\hline Albumen weight $_{2}(\mathrm{~g})$ & $6.270 \pm 0.076^{\mathrm{a}}$ & $5.126 \pm 0.069^{c}$ & $5.706 \pm 0.079^{b}$ & $5.367 \pm 0.056^{\mathrm{c}}$ \\
\hline Yolk weight $_{2}(\mathrm{~g})$ & $3.770 \pm 0.048^{\mathrm{a}}$ & $3.262 \pm 0.050^{b}$ & $3.526 \pm 0.057^{\mathrm{a}}$ & $3.701 \pm 0.038^{\mathrm{a}}$ \\
\hline Egg shell weight $2(\mathrm{~g})$ & $1.367 \pm 0.016^{\mathrm{a}}$ & $1.201 \pm 0.017^{b c}$ & $1.255 \pm 0.020^{b}$ & $1.155 \pm 0.013^{c}$ \\
\hline Egg equator thickness $2(\mathrm{~mm})$ & $0.298 \pm 0.003^{a b}$ & $0.284 \pm 0.003^{c}$ & $0.308 \pm 0.003^{\mathrm{a}}$ & $0.291 \pm 0.002^{b c}$ \\
\hline Yolk color-lightness 2 & $58.464 \pm 0.258^{b}$ & $58.838 \pm 0.290^{b}$ & $60.417 \pm 0.351^{\mathrm{a}}$ & $58.602 \pm 0.162^{b}$ \\
\hline Yolk color-redness 2 & $8.897 \pm 0.260^{\mathrm{a}}$ & $7.918 \pm 0.371^{\mathrm{ab}}$ & $6.238 \pm 0.508^{b}$ & $2.999 \pm 0.256^{\mathrm{c}}$ \\
\hline Yolk color-yellowness 2 & $41.081 \pm 0.357^{\mathrm{a}}$ & $41.231 \pm 0.346^{\mathrm{a}}$ & $38.221 \pm 0.478^{b}$ & $37.155 \pm 0.217^{b}$ \\
\hline Age at first egg & $46.120 \pm 0.505^{b}$ & $44.240 \pm 0.923 b c$ & $42.280 \pm 0.621^{\mathrm{c}}$ & $49.007 \pm 0.444^{\mathrm{a}}$ \\
\hline Total laid eggs & $56.900 \pm 1.169^{a}$ & $57.000 \pm 1.430^{\mathrm{a}}$ & $59.240 \pm 2.310^{a}$ & $47.819 \pm 0.782^{b}$ \\
\hline Egg production rate & $0.862 \pm 0.015^{\mathrm{a}}$ & $0.838 \pm 0.016^{\mathrm{a}}$ & $0.849 \pm 0.032^{\mathrm{a}}$ & $0.759 \pm 0.011^{b}$ \\
\hline
\end{tabular}

${ }^{\mathrm{a}-\mathrm{d}}$ Means with different superscript letters are significantly different between the traits (Tukey's HSD test, $p<0.05$ ). 1,2 Subscript letters are first and second egg laying stages. 


\subsection{RAD Sequencing and SNP Markers}

The Illumina HiSeq 2500 yielded 123,700,031 RAD-seq reads for $\mathrm{F}_{2}$ birds. After removing the uninformative markers, a total of 25,631 SNP markers were identified. Four hundred twenty-five SNPs were excluded that did not fit the Chi-squared goodness-offit test $(p<0.05)$. Out of the remaining 25,206 SNPs, 9843 markers were discarded that genotyped at least $90 \%$ of all $\mathrm{F}_{2}$ individuals. After stringent filtration, 14,659 SNPs with a low level of heterozygosity in the $\mathrm{F}_{1}$ parents were removed. After quality-based filtering, 571 SNPs were discarded from further analyses to reduce missing and wrongly called SNPs. A total of 133 high-fidelity SNP with fixed genotypes in both parents were obtained after excluding those with a deviation for the Mendelian segregation pattern. The QTX Map manager detected 15 unlinked markers that were excluded. Finally, 118 SNP markers were found to be informative between the parental strains.

\subsection{Linkage Map}

A linkage map was successfully drawn using the selected markers in Figure 1. The summary statistics of the constructed genetic map shown in Table 2. Linkage maps contained 118 SNP markers arranged in 13 linkage groups. The chromosome $\mathrm{Z}$ in this study was divided into two linkage groups. Each linkage group contained 2 to 32 SNPs. The length of Linkage groups ranged from 0 to $205.3 \mathrm{cM}$. SNPs covered $776.1 \mathrm{cM}$ of total genetic length with an average spacing of $7.4 \mathrm{cM}$.

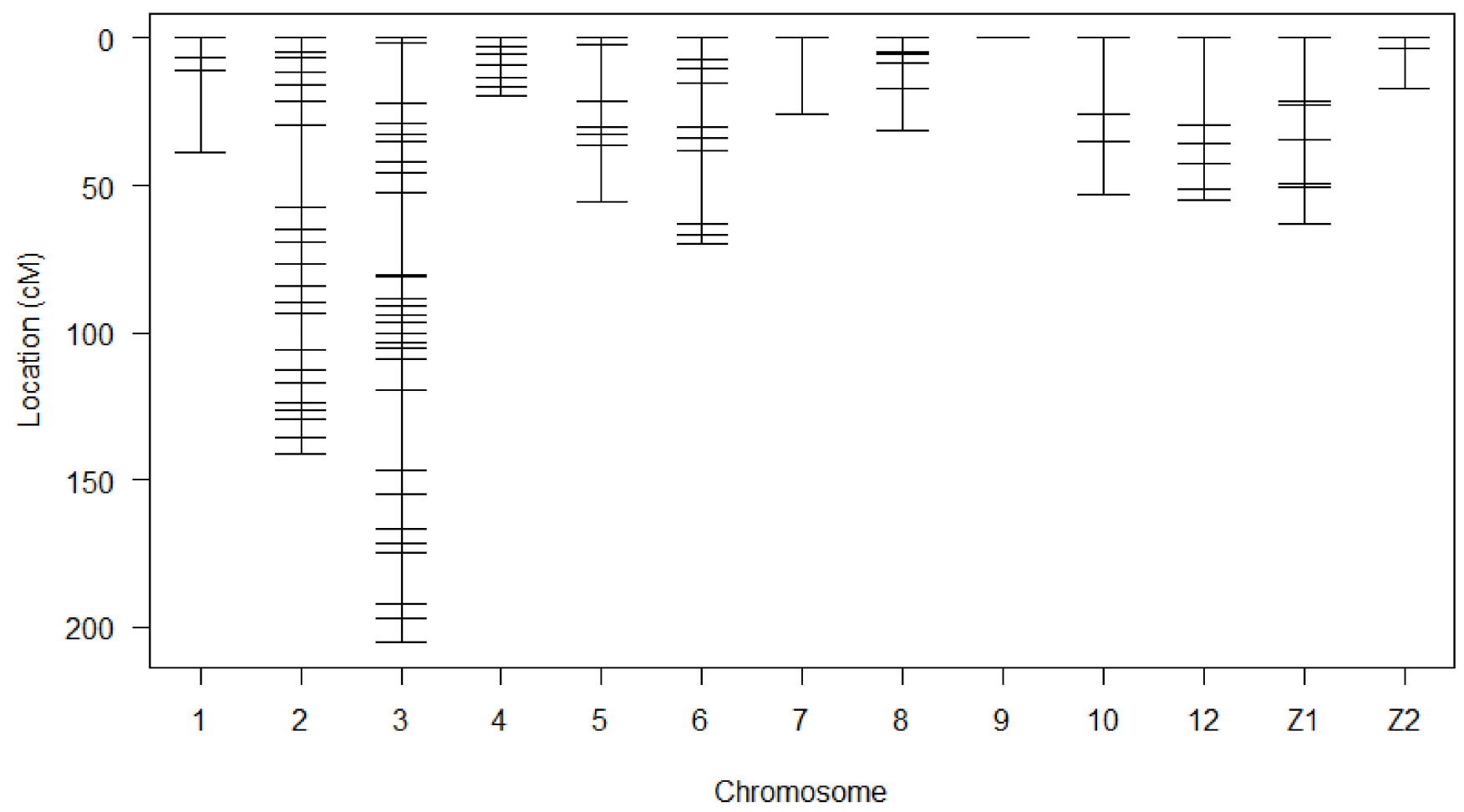

Figure 1. Genetic map of SNP markers distributed on 13 linkage groups. The abscissa shows the chromosome number. The ordinate presents the marker position based on $\mathrm{cM}$. 
Table 2. Summary of the genetic map constructed in this study.

\begin{tabular}{ccccc}
\hline $\begin{array}{c}\text { Chromosome } \\
\text { No. }{ }^{\mathbf{1}}\end{array}$ & No. of Markers & $\begin{array}{c}\text { Genetic Length } \\
\text { (cM) }\end{array}$ & $\begin{array}{c}\text { Average } \\
\text { Spacing (cM) }\end{array}$ & $\begin{array}{c}\text { Maximum } \\
\text { Spacing (cM) }\end{array}$ \\
\hline 1 & 4 & 39.0 & 13.0 & 28.3 \\
2 & 23 & 141.3 & 6.4 & 28.0 \\
3 & 32 & 205.3 & 6.6 & 27.5 \\
4 & 7 & 19.7 & 3.3 & 4.5 \\
5 & 8 & 55.3 & 7.9 & 19.1 \\
6 & 10 & 69.9 & 7.8 & 24.6 \\
7 & 2 & 26.0 & 26.0 & 26.0 \\
8 & 7 & 31.1 & 5.2 & 14.0 \\
9 & 2 & 0.0 & 0.0 & 0.0 \\
10 & 4 & 53.3 & 17.8 & 26.0 \\
12 & 6 & 55.1 & 11.0 & 29.5 \\
Z1 & 9 & 63.2 & 7.9 & 21.2 \\
Z2 & 4 & 16.9 & 5.6 & 13.3 \\
\hline overall & 118 & 776.1 & 7.4 & 29.5 \\
\hline
\end{tabular}

${ }^{1}$ Chromosome $\mathrm{Z}$ was divided into two linkage groups.

\subsection{QTL Detection}

Nine main-effect QTL were detected on chromosomes 2, 4, 6, 10, 12, and Z (Table 3). Genome-wide significant and suggestive levels for simple interval mapping calculated were 2.963-4.562 in LOD score for the detected QTL. Genome-wide LOD plots for detected QTL are shown in Figures 2-5. The plot of a phenotype against the genotypes at a marker for the identified QTL was drawn in Supplementary Figures S1-S12. Two genome-wide significant and suggestive QTL were found on chromosome 2 for AFE and $Y C-b^{*}{ }_{2}$, respectively. QTL for AFE was located at $108.0 \mathrm{cM}$ with $10.4 \%$ of phenotypic variance, and $\mathrm{YC}-\mathrm{b}_{2}{ }_{2}$ QTL positioned $123.5 \mathrm{cM}$ with a phenotypic variance of $9.9 \%$. A single genome-wide suggestive QTL was detected for ELA 1 located at $13.3 \mathrm{cM}$ on chromosome 4 . The detected QTL on chromosome 6 were located at 54.0 and $69.0 \mathrm{cM}$, which were responsible for $\mathrm{YW}_{1}$ and $\mathrm{ESS}_{1}$, respectively. Discovered QTL on chromosome 10 affected $\mathrm{EW}_{1}, \mathrm{ESA}_{1}, \mathrm{AW}_{1}$, and $\mathrm{YW}_{1}$ traits that ranged in the same flanking markers $(0.0-26.0 \mathrm{cM})$. A genome-wide suggestive QTL was found for $\mathrm{ESW}_{1}$ located on chromosome 12 between the confidence interval of $4.0-42.0 \mathrm{cM}$ with $10.0 \%$ of phenotypic variance and positive additive (0.063) and dominant (0.041) effects. The $\mathrm{Z}$ chromosome presented two QTL for $\mathrm{ESA}_{1}$ and $\mathrm{YD}_{1}$ positioned at 49.4 and $52.0 \mathrm{cM}$, respectively. Detected QTL are shown in the genetic map in Figure 6.

Table 3. Summary of QTL detected for egg-related traits.

\begin{tabular}{|c|c|c|c|c|c|c|c|c|c|c|c|}
\hline QTL\# & Traits & Chr. & $\begin{array}{l}\text { Position } \\
\text { (cM) }^{1}\end{array}$ & $\begin{array}{l}\text { Flanking Markers } \\
\text { (cM) }{ }^{2}\end{array}$ & LOD $^{3}$ & Interval (cM) ${ }^{4}$ & $\begin{array}{l}\text { Var. } \\
(\%)\end{array}$ & Add. ${ }^{6} \pm \mathrm{SE}$ & Dom. ${ }^{7} \pm \mathrm{SE}$ & $\mathrm{d} / \mathbf{a}^{8}$ & NS/LS 9 \\
\hline 1 & Age at first egg & 2 & 108.0 & $105.6-112.6$ & $3.295^{*}$ & $13.0-138.0$ & 10.4 & $-1.17 \pm 0.544$ & $-2.784 \pm 0.839$ & 2.387 & $\mathrm{~A} / \mathrm{B}$ \\
\hline 2 & Yolk color-yellowness ${ }_{2}$ & 2 & 123.5 & 123.5 & $3.108^{\dagger}$ & $0.0-141.3$ & 9.9 & $-1.02 \pm 0.27$ & $-0.218 \pm 0.369$ & 0.214 & $\mathrm{~A} / \mathrm{B}$ \\
\hline 3 & Egg long axis ${ }_{1}$ & 4 & 13.3 & 13.3 & $3.135^{\dagger}$ & $0.0-19.7$ & 9.9 & $0.366 \pm 0.125$ & $-0.461 \pm 0.188$ & -1.258 & $\mathrm{~B} / \mathrm{A}$ \\
\hline 4 & Yolk weight 1 & 6 & 54.0 & $38.2-62.8$ & $3.11^{\dagger}$ & $3.0-69.9$ & 8.5 & $-0.14 \pm 0.042$ & $0.136 \pm 0.069$ & -1.008 & $\mathrm{~A} / \mathrm{B}$ \\
\hline 5 & Egg shell strength 1 & 6 & 69.0 & $66.9-69.9$ & $3.359 *$ & $53.0-69.9$ & 10.6 & $0.073 \pm 0.02$ & $-0.05 \pm 0.027$ & -0.688 & $\mathrm{~A} / \mathrm{B}$ \\
\hline \multirow[t]{4}{*}{6} & Egg weight $t_{1}$ & 10 & 21.0 & $0.0-26.0$ & 4.151 ** & $2.0-51.0$ & 12.9 & $-0.47 \pm 0.108$ & $-0.322 \pm 0.163$ & 0.687 & $\mathrm{~A} / \mathrm{B}$ \\
\hline & Egg short axis 1 & 10 & 20.0 & $0.0-26.0$ & $3.552 *$ & $2.0-52.0$ & 8.0 & $-0.34 \pm 0.099$ & $-0.273 \pm 0.156$ & 0.806 & $\mathrm{~A} / \mathrm{B}$ \\
\hline & Albumen weight $t_{1}$ & 10 & 21.0 & $0.0-26.0$ & $4.374^{* *}$ & $5.0-48.0$ & 13.6 & $-0.27 \pm 0.06$ & $-0.199 \pm 0.092$ & 0.745 & $\mathrm{~A} / \mathrm{B}$ \\
\hline & Yolk weight 1 & 10 & 20.0 & $0.0-26.0$ & $2.963^{\dagger}$ & $0.0-53.3$ & 8.1 & $-0.15 \pm 0.041$ & $-0.1 \pm 0.063$ & 0.684 & $\mathrm{~A} / \mathrm{B}$ \\
\hline 7 & Egg shell weight 1 & 12 & 39.0 & $35.6-42.7$ & $3.157^{\dagger}$ & $4.0-42.0$ & 10.0 & $0.063 \pm 0.017$ & $0.041 \pm 0.026$ & 0.658 & $\mathrm{~B} / \mathrm{A}$ \\
\hline 8 & Egg short axis ${ }_{1}$ & $\mathrm{Z} 1$ & 49.4 & 49.4 & $3.093^{\dagger}$ & $28.0-63.2$ & 6.8 & $0.194 \pm 0.059$ & & & $\mathrm{~B} / \mathrm{A}$ \\
\hline 9 & Yolk diameter 1 & $\mathrm{Z1}$ & 52.0 & $50.3-63.2$ & $4.562 * *$ & $24.0-63.0$ & 14.1 & $0.396 \pm 0.091$ & & & $\mathrm{~B} / \mathrm{A}$ \\
\hline
\end{tabular}

1,2 Subscript letters are first and second egg laying stages; ${ }^{1}$ peak position; ${ }^{2}$ physical position of the marker; ${ }^{3}$ genome-wide significant and suggestive QTL (** significant at $1 \%$ and $* 5 \%$ level, ${ }^{\dagger}$ suggestive at $10 \%$ level); ${ }^{4}$ confidence interval at 1.8 -LOD drop-off; ${ }^{5}$ phenotypic variance explained by QTL; ${ }^{6}$ additive effect of the QTL; ${ }^{7}$ dominant effect of the QTL; ${ }^{8}$ the degree of dominance; ${ }^{9}$ parental allele. 


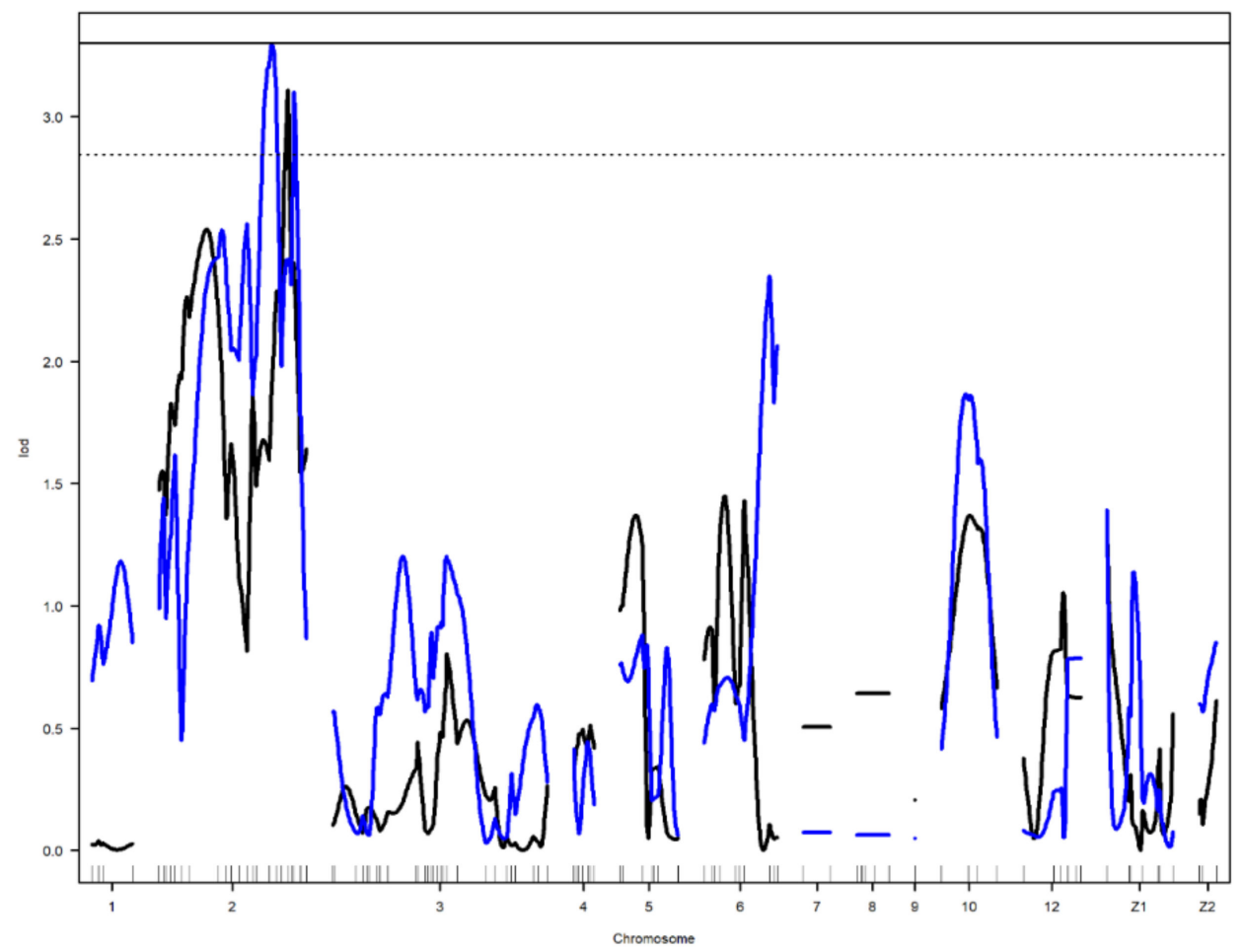

Figure 2. Genome-wide LOD plot of detected QTL for age at first egg (blue) and yolk coloryellowness 2 (black) on chromosome 2 . The horizontal lines show the genome-wide significance at $5 \%$ (straight line) and suggestive threshold at 10\% (dotted line) levels.

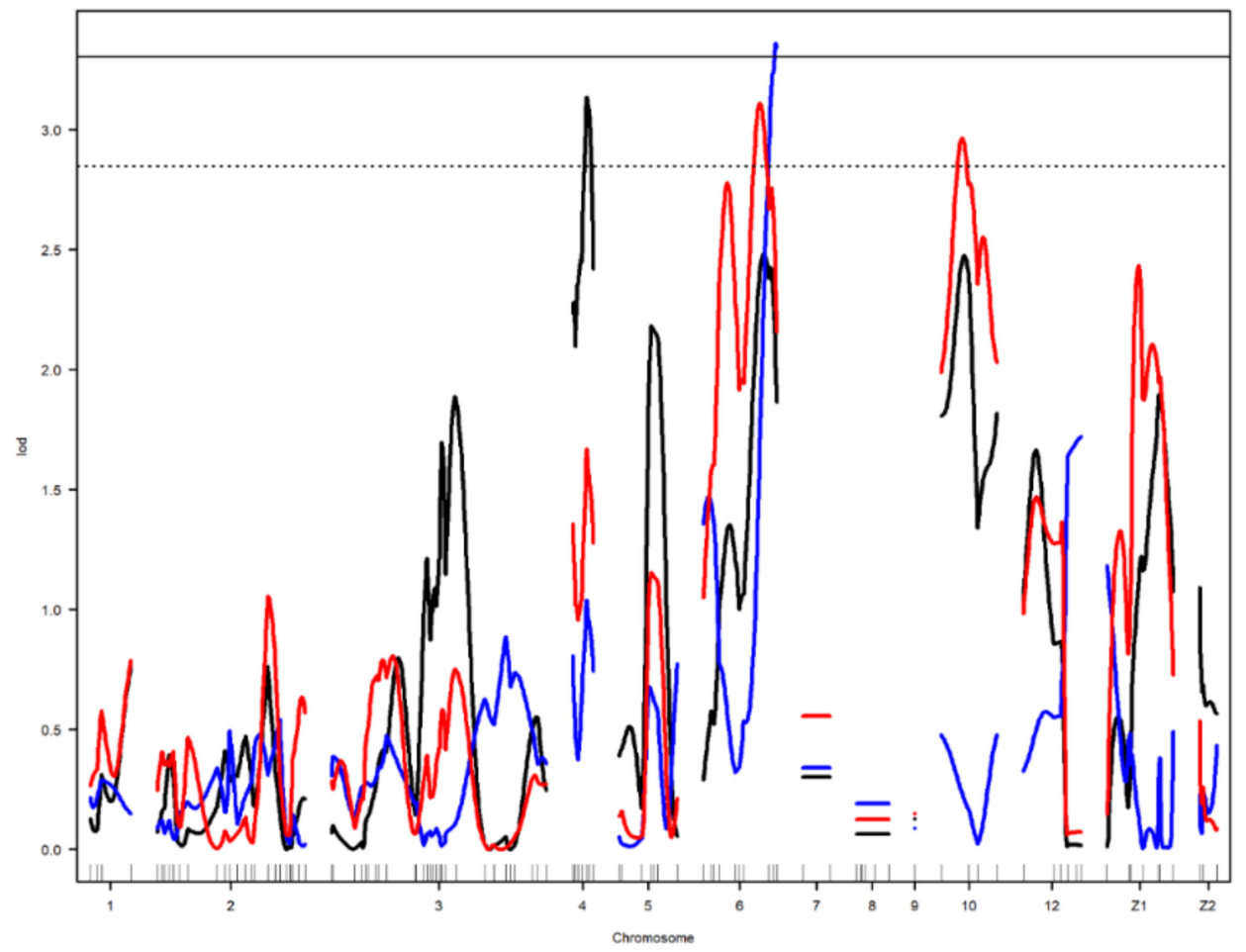

Figure 3. Genome-wide LOD plot of detected QTL for egg long axis ${ }_{1}$ (black) on chromosome 4,

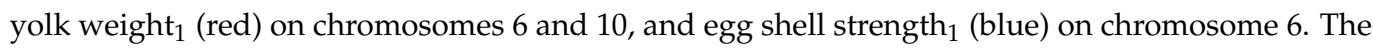
horizontal lines show the genome-wide significance at $5 \%$ (straight line) and suggestive threshold at $10 \%$ (dotted line) levels. 


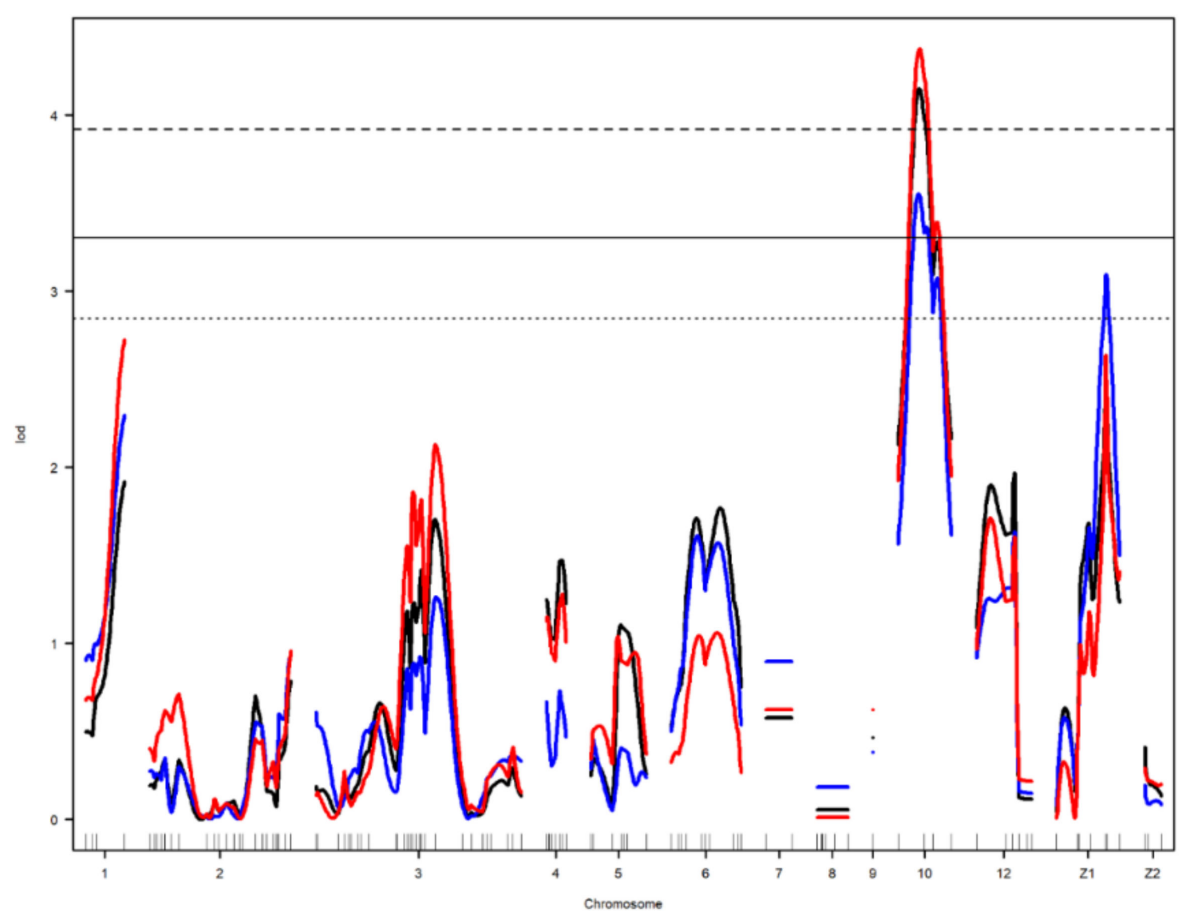

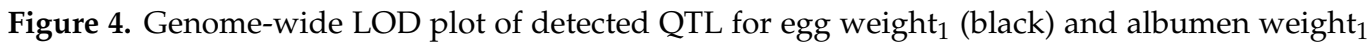
(red) on chromosome 10, and egg short axis 1 (blue) on chromosomes 10 and Z1. The horizontal lines show the genome-wide significance threshold at $1 \%$ (dashed line) and 5\% (straight line) and suggestive threshold at $10 \%$ (dotted line) levels.

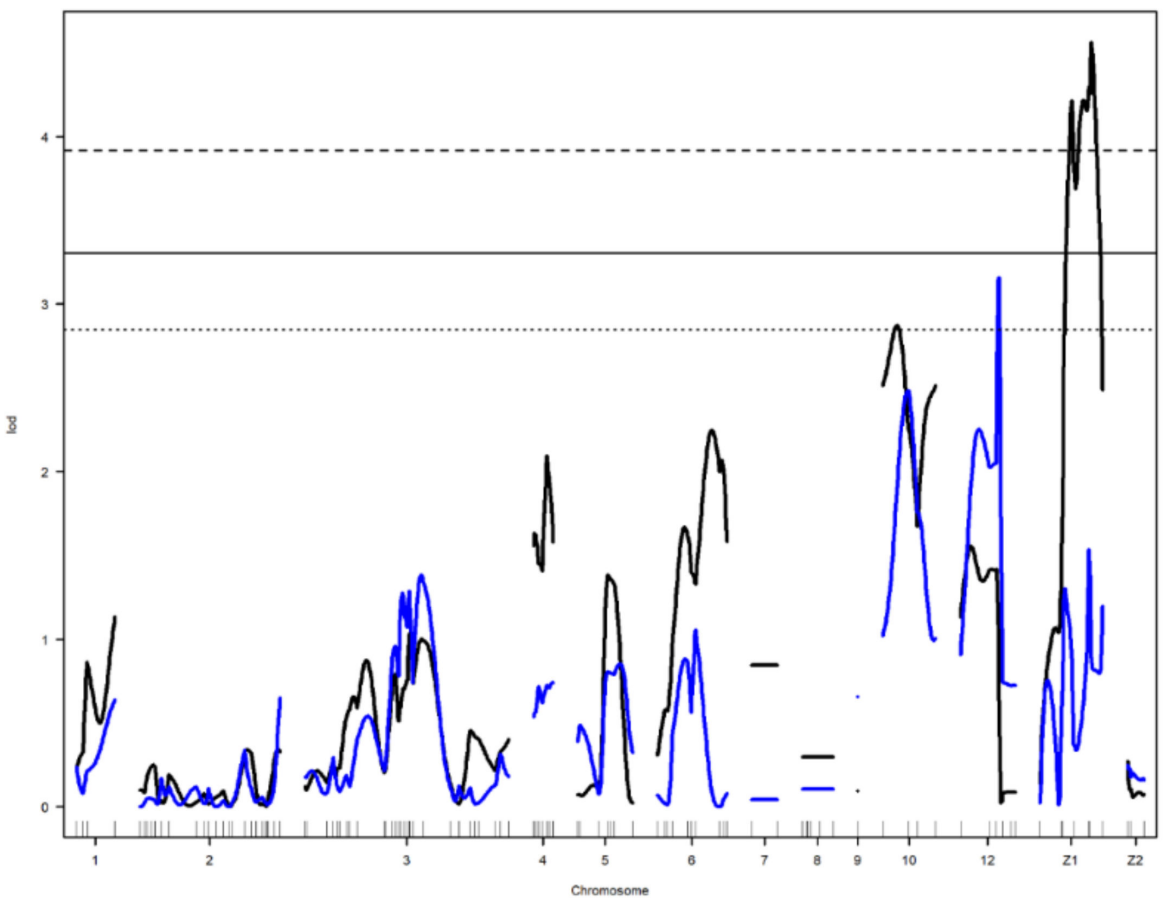

Figure 5. Genome-wide LOD plot of detected QTL for egg shell weight 1 (blue) on chromosome 12 and yolk diameter 1 (black) on chromosome Z1. The horizontal lines show the genome-wide significance threshold at 1\% (dashed line) and 5\% (straight line) and suggestive threshold at 10\% (dotted line) levels. 


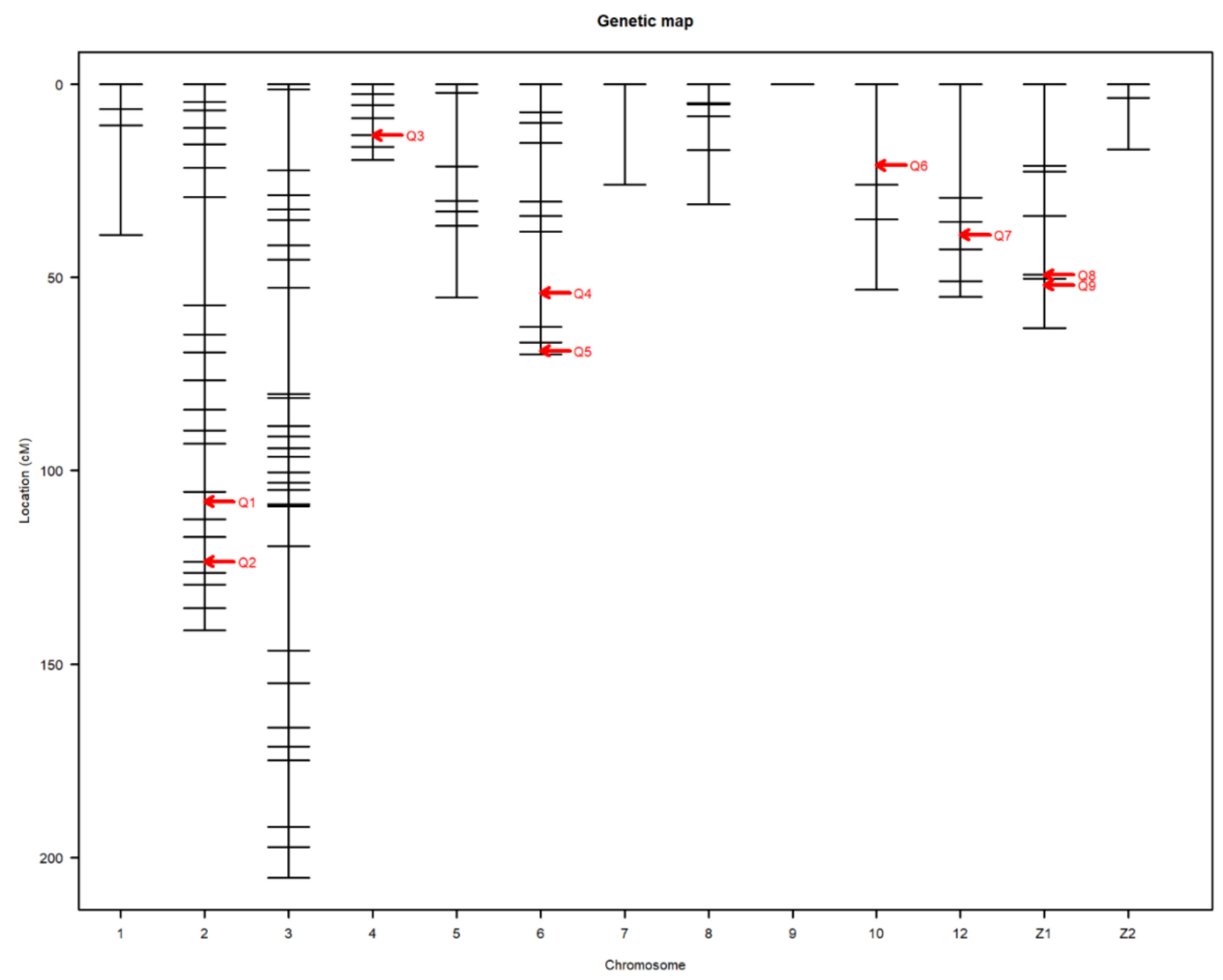

Figure 6. Detected QTL presented in the genetic map. The abscissa shows the chromosome number. The ordinate represents the position of the markers based on cM. Q stands for the QTL number.

\section{Discussion}

The present study revealed nine QTL for 10 egg-related traits $\left(\mathrm{EW}_{1}, \mathrm{ELA}_{1}, \mathrm{ESA}_{1}, \mathrm{ESS}_{1}\right.$, $\mathrm{YD}_{1}, \mathrm{AW}_{1}, \mathrm{YW}_{1}, \mathrm{ESW}_{1}, \mathrm{YC}-\mathrm{b}_{2}{ }_{2}$, and AFE) in $138 \mathrm{~F}_{2}$ female Japanese quails. To the best of our knowledge, four studies have conducted QTL analysis on egg-quality and -production traits in the Japanese quail. In these studies, fewer egg-related traits and markers were used for QTL analysis. As the Japanese quail is a model bird in Galliformes, the data obtained in quail can be applied to other bird species, especially in chickens. In addition, the Japanese quail shows close phylogenetic relatedness to chickens with similar length of genome, chromosome number, and morphology of chromosomes. Therefore, a high rate of contiguity, assembly statistics, gene content, chromosomal organization, and synteny conservation exists between the two species [42,80]. Knaga et al. [31] reported QTL for the egg number and egg production rate at positions 36 to $42 \mathrm{cM}$ on chromosome 1 using 30 microsatellite markers. Minvielle et al. [52] reported QTL for egg number and age at first egg positioned at 32 and $34 \mathrm{cM}$, respectively, on chromosome 6. Recoquillay et al. [51] reported QTL for egg number on chromosomes $3(225 \mathrm{cM})$ and $18(3 \mathrm{cM})$ and QTL for age at first egg on chromosomes $3(302 \mathrm{cM})$ and $19(4 \mathrm{cM})$. The results of the current study detected a QTL for AFE located on chromosome 2. However, we did not reveal any QTL for EPR and TLE in the present study. The discrepancy in the number of laid eggs between the results of the present study and those of previous studies may be related to the different durations of the egg collection period. The results of this study are in line with those of Goraga et al. [81], who found QTL for AFE on chromosome 2 in chickens.

The present study found a genome-wide significant QTL for EW at the first stage of egg-laying on chromosome 10 positioned at $21.0 \mathrm{cM}$. A QTL responsible for EW was reported on chromosome 1 at a position of $4 \mathrm{cM}$ for the Japanese quail [31]. A previous study identified four QTL for the EW trait on chromosomes 1, 3, 18, and 18 positioned at 193, 156, 61, and $62 \mathrm{cM}$, respectively [51]. At position $0 \mathrm{cM}$ on chromosome 6, a QTL mapped for EW was reported in Japanese quail eggs [52]. The differences in the positions and chromosome numbers of detected QTL for EW may be related to the different periods of 
weight determination and suggest that other genes exert an effect during the laying period rather than at a later age [31]. In chickens, QTL for the first egg weight were determined on chromosomes 4 and 8 at 213 and $40 \mathrm{cM}$, respectively [47]. In addition, QTL underlying EW at later ages have been reported on chromosomes 8 and 10 in chickens $[47,82]$.

A genome-wide suggestive QTL was found for ESW at the first stage of egg-laying on chromosome 12 in the current study. In turn, studies of ESW in the Japanese quail have reported QTL on chromosome 1 [31] and chromosomes 1, 5, and 20 [52]. A similar result was found in the case of chickens in which QTL associated with ESW was mapped on chromosome 12 with a confidence interval of 0-71 cM [83]. The discrepancy between the findings of QTL for ESW in the Japanese quail may be due to different times during the production period for determining ESW or the lack of a single preferred way to measure the shell weight. Therefore, it is important to identify QTL that differ over time for the traits of interest.

To date, no QTL have been detected for AW and YW in Japanese quail eggs. This study is the first to report QTL for AW and YW. However, QTL detection for AW and YW has been reported in chickens to be located on chromosomes 2, 3, 4, 7, and 8 for AW and $1-6,8,9,11,13,15,17,22,23,26,28$, and $Z$ chromosomes for $Y W[12,46,50,82,84,85]$. No QTL were reported for AW and YW on chromosome 10 in chickens. In the present study, the detected QTL for YW on chromosome 6 did not overlap with the previous study in chickens [82]. This might be due to the differences in crosses designed for both studies or ages of the two species used, as genetic control for YW is age-dependent. The AW and YW traits are influenced by the age of quails. AW and YW increase with the age of the females. For eggs of the same size, old quails produce larger AW and YW than do young quails. However, in chickens, the genetic correlations among AW and YW at different age points are relatively high $[46,85]$.

To date, there have been no studies detecting QTL for ELA, ESA, ESS, YD, and YC in Japanese quail eggs. This is the first study to detect QTL for ELA $1, \mathrm{ESA}_{1}, \mathrm{ESS}_{1}, \mathrm{YD}_{1}$, and $Y C-b^{*}{ }_{2}$ traits in the Japanese quail. Nevertheless, there are available QTL for these traits in chickens. Sasaki et al. [86] found a QTL underlying ELA on the same chromosome as that in the current study. The presence of QTL for ESA at the early stage of egg production was reported on chromosomes 10 and $\mathrm{Z}$ positioned at 4 and $85 \mathrm{cM}$, respectively [47]. The positions of the two QTL for ESA are not in line with the positions of QTL on chromosomes 10 and $\mathrm{Z}$ for $\mathrm{ESA}_{1}$ in the current investigation. Similar to the present study, QTL for ESS have been reported on chromosome 6 in chickens [82]. However, Goto et al. [47] found a QTL for ESS on the Z chromosome at the beginning stage of egg production, positioned at $51 \mathrm{cM}$. In the present study, a QTL for $\mathrm{YD}_{1}$ was mapped on the $\mathrm{Z}$ chromosome. However, no QTL have been reported for yolk index on this chromosome in chickens. Detected QTL for the yolk index in chickens were located on chromosomes 2, 8, and 17 [46,87]. The presence of novel QTL and mapping information is very important for understanding the genetic basis of egg-related traits.

An important biophysical parameter of egg yolk is its color, which plays a very important role in the perception of food and is also a key aspect of food quality. In the current study, one QTL for the yellowness of yolk color at the second stage of egg laying was detected on chromosome 2. QTL for yolk color were also identified on chromosomes $1-4,8,9$, and 27 in chickens $[46,50,88,89]$. There is a discrepancy between the findings of this study and those of chickens. It is suggested that the different methods used for the measurement of $Y C$ in the current study and the literature on chickens may account for the inconsistent results.

The findings of this investigation suggest that egg-related traits are regulated by many QTL at different growth stages associated with the importance of egg quality and production in breeding programs for poultry industries. These findings may help to develop the Japanese quail QTL database, which can be applied to other Galliformes species, especially chickens. Detected QTL affecting egg-related traits provides necessary information for further molecular studies to improve quantitative traits. It would be 
desirable to perform a deeper analysis of detected loci using an expanded dataset and sequence information to assess the potential of the found QTL for MAS. Japanese quail can be a valuable resource for the poultry industry sector, and the results of the current study may enable poultry breeders and industries to develop good breeding strategies based on future MAS studies. In conclusion, we determined nine main-effect QTL that affect eggrelated traits using LS and NS Japanese quail strains. This is the first study to report quail QTL information determined using RAD-seq method, including the detection of many trait-regulating QTL that have never been reported before. Thus, these findings will help us understand the genetic basis of egg-related traits and assist breeders in implementing effective selection programs based on MAS.

Supplementary Materials: The following are available online at https:/ / www.mdpi.com/article/ 10.3390/genes12050735/s1, Figure S1: Plot of the phenotype against the genotypes for age at first egg QTL detected on chromosome 2, Figure S2: Plot of the phenotype against the genotypes for yolk color-yellowness ${ }_{2}$ QTL detected on chromosome 2, Figure S3: Plot of the phenotype against the genotypes for egg long axis 1 QTL detected on chromosome 4, Figure S4: Plot of the phenotype against the genotypes for yolk weight ${ }_{1}$ QTL detected on chromosome 6, Figure S5: Plot of the phenotype against the genotypes for egg shell strength 1 QTL detected on chromosome 6, Figure S6: Plot of the phenotype against the genotypes for egg weight $t_{1}$ QTL detected on chromosome 10, Figure S7: Plot of the phenotype against the genotypes for egg short axis 1 QTL detected on chromosome 10, Figure S8: Plot of the phenotype against the genotypes for albumen weight ${ }_{1}$ QTL detected on chromosome 10, Figure S9: Plot of the phenotype against the genotypes for yolk weight ${ }_{1}$ QTL detected on chromosome 10, Figure S10: Plot of the phenotype against the genotypes for egg shell weight ${ }_{1}$ QTL detected on chromosome 12, Figure S11: Plot of the phenotype against the genotypes for egg short axis 1 QTL detected on Z chromosome, Figure S12: Plot of the phenotype against the genotypes for yolk diameter 1 QTL detected on $Z$ chromosome.

Author Contributions: Conceptualization, M.T., execution of the experiments, M.I.H., contribution to materials and reagents, A.T., RAD-sequencing, A.J.N., software, validation, and formal analysis, M.I.H., S.N., M.N., T.G., Y.N., A.I., writing-original draft, M.I.H., writing-review and editing, T.G., A.I., M.T., supervision, M.T. All authors have read and agreed to the published version of the manuscript.

Funding: This research received no external funding.

Institutional Review Board Statement: The study was conducted according to the Rules on Experimental Animals and Animal Experiments in Hiroshima University (Protocol No. 4, 17 January 2020) by the Hiroshima University Animal Research Committee.

Informed Consent Statement: Not applicable.

Acknowledgments: M.I.H. is grateful to the Honjo International Scholarship Foundation for providing scholarships. The authors thank L. Kawaguchi for assistance with the RAD-seq analysis and the members of the Laboratory of Animal Breeding and Genetics at Hiroshima University for their collaboration and support.

Conflicts of Interest: The authors have no conflicts of interest to declare.

\section{References}

1. Mackay, T.F.C. Epistasis and quantitative traits: Using model organisms to study gene-gene interactions. Nat. Rev. Genet. 2014, 15, 22-33. [CrossRef]

2. Rosochacki, S.J.; Olszewski, R.; Wardecka, B.; Jaszczak, K.; Zieba, G.; Juszcsuk-Kubiak, E.; Poloszynowicz, J. Mapping of QTL controlling egg quality on chromosomes 6-8, Z and three linkage groups in chickens. Iran. J. Appl. Anim. Sci. 2013, 3, 369-378.

3. Albert, F.W.; Kruglyak, L. The role of regulatory variation in complex traits and disease. Nat. Rev. Genet. 2015, 16, 197-212. [CrossRef] [PubMed]

4. Moreira, G.C.M.; Salvian, M.; Boschiero, C.; Cesar, A.S.M.; Reecy, J.M.; Godoy, T.F.; Ledur, M.C.; Garrick, D.; Mourão, G.B.; Coutinho, L.L. Genome-wide association scan for QTL and their positional candidate genes associated with internal organ traits in chickens. BMC Genom. 2019, 20, 669. [CrossRef]

5. Torkamanzehi, A.; Kuhnlein, U. Restriction fragment length and single strand conformational polymorphisms in chicken mitochondrial phosphoenol-pyruate carboxykinase gene and its association with egg production. Pak. J. Biol. Sci. 2007, 10, 4075-4080. [CrossRef] [PubMed] 
6. Frésard, L.; Leroux, S.; Dehais, P.; Servin, B.; Gilbert, H.; Bouchez, O.; Klopp, C.; Cabau, C.; Vignoles, F.; Feve, K.; et al. Fine mapping of complex traits in non-model species: Using next generation sequencing and advanced intercross lines in Japanese quail. BMC Genom. 2012, 13, 551. [CrossRef]

7. Tsudzuki, M.; Onitsuka, S.; Akiyama, R.; Iwamizu, M.; Goto, N.; Nishibori, M.; Takahashi, H.; Ishikawa, A. Identification of quantitative trait loci affecting shank length, body weight and carcass weight from the Japanese cockfighting chicken breed, Oh-Shamo (Japanese Large Game). Cytogenet. Genome Res. 2007, 117, 288-295. [CrossRef] [PubMed]

8. Laoun, A.; Harkat, S.; Lafri, M.; Gaouar, S.B.S.; Belabdi, I.; Ciani, E.; De Groot, M.; Blanquet, V.; Leroy, G.; Rognon, X.; et al. Inference of breed structure in farm animals: Empirical comparison between SNP and microsatellite performance. Genes 2020, 11, 57. [CrossRef] [PubMed]

9. Loureiro, L.O.; Engstrom, M.D.; Lim, B.K. Single nucleotide polymorphisms (SNPs) provide unprecedented resolution of species boundaries, phylogenetic relationships, and genetic diversity in the mastiff bats (Molossus). Mol. Phylogenet. Evol. 2020, 143, 106690. [CrossRef] [PubMed]

10. Morenikeji, O.B.; Capria, A.L.; Ojurongbe, O.; Thomas, B.N. SNP diversity in CD14 gene promoter suggests adaptation footprints in trypanosome tolerant N'Dama (Bos taurus) but not in susceptible White Fulani (Bos indicus) cattle. Genes 2020, 11, 112. [CrossRef]

11. von Thaden, V.A.; Nowak, C.; Tiesmeyer, A.; Reiners, T.E.; Alves, P.C.; Lyons, L.A.; Mattucci, F.; Randi, E.; Cragnolini, M.; Galián, J.; et al. Applying genomic data in wildlife monitoring: Development guidelines for genotyping degraded samples with reduced single nucleotide polymorphism panels. Mol. Ecol. Resour. 2020, 20, 662-680. [CrossRef]

12. Wolc, A.; Arango, J.; Jankowski, T.; Dunn, I.; Settar, P.; Fulton, J.E.; O'Sullivan, N.P.; Preisinger, R.; Fernando, R.L.; Garrick, D.J.; et al. Genome-wide association study for egg production and quality in layer chickens. J. Anim. Breed. Genet. 2014, 131, 173-182. [CrossRef] [PubMed]

13. Beuzen, N.D.; Stear, M.J.; Chang, K.C. Molecular markers and their use in animal breeding. Vet. J. 2000, 160, 42-52. [CrossRef] [PubMed]

14. Robledo, D.; Palaiokostas, C.; Bargelloni, L.; Martínez, P.; Houston, R. Applications of genotyping by sequencing in aquaculture breeding and genetics. Rev. Aquac. 2018, 10, 670-682. [CrossRef]

15. Davey, J.W.; Hohenlohe, P.A.; Etter, P.D.; Boone, J.Q.; Catchen, J.M.; Blaxter, M.L. Genome-wide genetic marker discovery and genotyping using next-generation sequencing. Nat. Rev. Genet. 2011, 12, 499-510. [CrossRef]

16. Elshire, R.J.; Glaubitz, J.C.; Sun, Q.; Poland, J.A.; Kawamoto, K.; Buckler, E.S.; Mitchell, S.E. A robust, simple genotyping-bysequencing (GBS) approach for high diversity species. PLoS ONE 2011, 6, e19379. [CrossRef]

17. De Donato, M.; Peters, S.O.; Mitchell, S.E.; Hussain, T.; Imumorin, I.G. Genotyping-by-sequencing (GBS): A novel, efficient and cost-effective genotyping method for cattle using next-generation sequencing. PLoS ONE 2013, 8, e62137. [CrossRef] [PubMed]

18. Sonah, H.; Bastien, M.; Iquira, E.; Tardivel, A.; Légaré, G.; Boyle, B.; Normandeau, É.; Laroche, J.; Larose, S.; Jean, M.; et al. An improved genotyping by sequencing (GBS) approach offering increased versatility and efficiency of SNP discovery and genotyping. PLoS ONE 2013, 8, e54603. [CrossRef] [PubMed]

19. Pértille, F.; Guerrero-Bosagna, C.; Silva, V.H.; Boschiero, C.; da Silva Nunes, J.D.R.; Ledur, M.C.; Jensen, P.; Coutinho, L.L. High-throughput and cost-effective chicken genotyping using next-generation sequencing. Sci. Rep. 2016, 6, 26929. [CrossRef]

20. Baird, N.A.; Etter, P.D.; Atwood, T.S.; Currey, M.C.; Shiver, A.L.; Lewis, Z.A.; Selker, E.U.; Cresko, W.A.; Johnson, E.A. Rapid SNP discovery and genetic mapping using sequenced RAD markers. PLoS ONE 2008, 3, e3376. [CrossRef] [PubMed]

21. Davey, J.W.; Blaxter, M.L. RADseq: Next-generation population genetics. Brief. Funct. Genom. 2010, 9, 416-423. [CrossRef]

22. Hohenlohe, P.A.; Bassham, S.; Etter, P.D.; Stiffler, N.; Johnson, E.A.; Cresko, W.A. Population genomics of parallel adaptation in threespine stickleback using sequenced RAD tags. PLoS Genet. 2010, 6, e1000862. [CrossRef]

23. Zhai, Z.; Zhao, W.; He, C.; Yang, K.; Tang, L.; Liu, S.; Zhang, Y.; Huang, Q.; Meng, H. SNP discovery and genotyping using restriction-site-associated DNA sequencing in chickens. Anim. Genet. 2015, 46, 216-219. [CrossRef]

24. Tsudzuki, M. Mutations of Japanese quail (Coturnix japonica) and recent advances of molecular genetics for this species. J. Poult. Sci. 2008, 45, 159-179. [CrossRef]

25. Minvielle, F. The future of Japanese quail for research and production. Worlds Poult. Sci. J. 2004, 60, 500-507. [CrossRef]

26. Jeke, A.; Phiri, C.; Chitindingu, K.; Taru, P. Ethnomedicinal use and pharmacological potential of Japanese quail (Coturnix coturnix japonica) birds' meat and eggs, and its potential implications on wild quail conservation in Zimbabwe: A review. Cogent Food Agric. 2018, 4, 1-12. [CrossRef]

27. Padgett, C.A.; Ivey, W.D. Coturnix quail as a laboratory research animal. Science 1959, 129, 267-268. [CrossRef] [PubMed]

28. Tsudzuki, M.; Nakane, Y.; Wada, A. Hereditary multiple malformation in Japanese quail: A possible powerful animal model for morphogenetic studies. J. Hered. 1998, 89, 24-31. [CrossRef] [PubMed]

29. Alsobayel, A.A.; Albadry, M.A. Effect of storage period and strain of layer on internal and external quality characteristics of eggs marketed in Riyadh area. J. Saudi Soc. Agric. Sci. 2011, 10, 41-45. [CrossRef]

30. Kirkwood, J.K.; Hubrecht, R. The UFAW Handbook on the Care and Management of Laboratory and Other Research Animals, 1st ed.; Wiley-Blackwell: Hoboken, NJ, USA, 2010; p. 837.

31. Knaga, S.; Siwek, M.; Tavaniello, S.; Maiorano, G.; Witkowski, A.; Jezewska-Witkowska, G.; Bednarczyk, M.; Zięba, G. Identification of quantitative trait loci affecting production and biochemical traits in a unique Japanese quail resource population. Poult. Sci. 2018, 97, 2267-2277. [CrossRef] [PubMed] 
32. Mannen, H.; Murata, K.; Kikuchi, S.; Fujima, D.; Sasazaki, S.; Fujiwara, A.; Tsuji, S. Development and mapping of microsatellite markers derived from cDNA in Japanese quail (Coturnix japonica). J. Poult. Sci. 2005, 42, 263-271. [CrossRef]

33. Kayang, B.B.; Inoue-Murayama, M.; Hoshi, T.; Matsuo, K.; Takahashi, H.; Minezawa, M.; Mizutani, M.; Ito, S. Microsatellite loci in Japanese quail and cross-species amplification in chicken and guinea fowl. Genet. Sel. Evol. 2002, 34, 233-253. [CrossRef] [PubMed]

34. Roussot, O.; Feve, K.; Plisson-Petit, F.; Pitel, F.; Faure, J.M.; Beaumont, C.; Vignal, A. AFLP linkage map of the Japanese quail Coturnix japonica. Genet. Sel. Evol. 2003, 35, 559-572. [CrossRef] [PubMed]

35. Kayang, B.B.; Vignal, A.; Inoue-Murayama, M.; Miwa, M.; Monvoisin, J.L.; Ito, S.; Minvielle, F. A first-generation microsatellite linkage map of the Japanese quail. Anim. Genet. 2004, 35, 195-200. [CrossRef] [PubMed]

36. Nishibori, M.; Hayashi, T.; Tsudzuki, M.; Yamamoto, Y.; Yasue, H. Complete sequence of the Japanese quail (Coturnix japonica) mitochondrial genome and its genetic relationship with related species. Anim. Genet. 2001, 32, 380-385. [CrossRef] [PubMed]

37. Tavaniello, S.; Maiorano, G.; Siwek, M.; Knaga, S.; Witkowski, A.; Di Memmo, D.; Bednarczyk, M. Growth performance, meat quality traits, and genetic mapping of quantitative trait loci in 3 generations of Japanese quail populations (Coturnix japonica). Poult. Sci. 2014, 93, 2129-2140. [CrossRef] [PubMed]

38. Minvielle, F.; Kayang, B.B.; Inoue-Murayama, M.; Miwa, M.; Vignal, A.; Gourichon, D.; Neau, A.; Monvoisin, J.L.; Ito, S. Search for QTL affecting the shape of the egg laying curve of the Japanese quail. BMC Genet. 2006, 7, 26. [CrossRef]

39. Charati, H.; Koshkoiyeh, A.E.; Ori, R.J.; Moradian, H.; Mehrgardi, A.A. Detection of quantitative trait loci affecting carcass traits and internal organs on chromosome 3 in an $\mathrm{F}_{2}$ intercross of Japanese quail. Anim. Sci. Pap. Rep. 2014, 32, 369-383.

40. Beaumont, C.; Roussot, O.; Feve, K.; Vignoles, F.; Leroux, S.; Pitel, F.; Faure, J.M.; Mills, A.D.; Guémené, D.; Sellier, N.; et al. A genome scan with AFLP ${ }^{\mathrm{TM}}$ markers to detect fearfulness-related QTLs in Japanese quail. Anim. Genet. 2005, 36, 401-407. [CrossRef]

41. Kayang, B.B.; Fillon, V.; Inoue-Murayama, M.; Miwa, M.; Leroux, S.; Fève, K.; Monvoisin, J.L.; Pitel, F.; Vignoles, M.; Mouilhayrat, C.; et al. Integrated maps in quail (Coturnix japonica) confirm the high degree of synteny conservation with chicken (Gallus gallus) despite 35 million years of divergence. BMC Genom. 2006, 7, 101. [CrossRef]

42. Shibusawa, M.; Minai, S.; Nishida-Umehara, C.; Suzuki, T.; Mano, T.; Yamada, K.; Namikawa, T.; Matsuda, Y. A comparative cytogenetic study of chromosome homology between chicken and Japanese quail. Cytogenet. Cell Genet. 2001, 95, 103-109. [CrossRef] [PubMed]

43. Chicken QTL Database. Available online: https://www.animalgenome.org/cgi-bin/QTLdb/GG/index (accessed on 23 February 2020).

44. Goto, T.; Ishikawa, A.; Onitsuka, S.; Goto, N.; Fujikawa, Y.; Umino, T.; Nishibor, M.; Tsudzuki, M. Mapping quantitative trait loci for egg production traits in an $\mathrm{F}_{2}$ intercross of Oh-Shamo and White Leghorn chickens. Anim. Genet. 2011, 42, 634-641. [CrossRef] [PubMed]

45. Yoshida, M.; Ishikawa, A.; Goto, T.; Goto, N.; Nishibori, M.; Tsudzuki, M. QTL mapping for meat color traits using the $F_{2}$ intercross between the Oh-Shamo (Japanese Large Game) and White Leghorn chickens. J. Poult. Sci. 2013, 50, 198-205. [CrossRef]

46. Goto, T.; Ishikawa, A.; Goto, N.; Nishibori, M.; Umino, T.; Tsudzuki, M. Mapping of main-effect and epistatic quantitative trait loci for internal egg traits in an $\mathrm{F}_{2}$ resource population of chickens. J. Poult. Sci. 2014, 51, 375-386. [CrossRef]

47. Goto, T.; Ishikawa, A.; Yoshida, M.; Goto, N.; Umino, T.; Nishibori, M.; Tsudzuki, M. Quantitative trait loci mapping for external egg traits in $\mathrm{F}_{2}$ chickens. J. Poult. Sci. 2014, 51, 118-129. [CrossRef]

48. Goto, T.; Tsudzuki, M. Genetic mapping of quantitative trait loci for egg production and egg quality traits in chickens: A review. J. Poult. Sci. 2017, 54, 1-12. [CrossRef]

49. Goto, T.; Ishikawa, A.; Nishibori, M.; Tsudzuki, M. A longitudinal quantitative trait locus mapping of chicken growth traits. Mol. Genet. Genom. 2019, 294, 243-252. [CrossRef] [PubMed]

50. Goto, T.; Fernandes, A.F.A.; Tsudzuki, M.; Rosa, G.J.M. Causal phenotypic networks for egg traits in an $\mathrm{F}_{2}$ chicken population. Mol. Genet. Genom. 2019, 294, 1455-1462. [CrossRef] [PubMed]

51. Recoquillay, J.; Pitel, F.; Arnould, C.; Leroux, S.; Dehais, P.; Moréno, C.; Calandreau, L.; Bertin, A.; Gourichon, D.; Bouchez, O.; et al. A medium density genetic map and QTL for behavioral and production traits in Japanese quail. BMC Genom. 2015, 16, 10. [CrossRef] [PubMed]

52. Minvielle, F.; Kayang, B.B.; Inoue-Murayama, M.; Miwa, M.; Vignal, A.; Gourichon, D.; Neau, A.; Monvoisin, J.L.; Ito, S. Microsatellite mapping of QTL affecting growth, feed consumption, egg production, tonic immobility and body temperature of Japanese quail. BMC Genom. 2005, 6, 87. [CrossRef] [PubMed]

53. Kawahara-Miki, R.; Sano, S.; Nunome, M.; Shimmura, T.; Kuwayama, T.; Takahashi, S.; Kawashima, T.; Matsuda, Y.; Yoshimura, T.; Kono, T. Next-generation sequencing reveals genomic features in the Japanese quail. Genomics 2013, 101, 345-353. [CrossRef] [PubMed]

54. Ono, T.; Kouguchi, T.; Ishikawa, A.; Nagano, A.J.; Takenouchi, A.; Igawa, T.; Tsudzuki, M. Quantitative trait loci mapping for the shear force value in breast muscle of $F_{2}$ chickens. Poult. Sci. 2019, 98, 1096-1101. [CrossRef] [PubMed]

55. Ono, T.; Ohara, K.; Ishikawa, A.; Kouguchi, T.; Nagano, A.J.; Takenouchi, A.; Igawa, T.; Tsudzuki, M. Mapping of quantitative trait loci for growth and carcass-related traits in chickens using a restriction-site associated DNA sequencing method. J. Poult. Sci. 2019, 56, 166-176. [CrossRef] 
56. Wan, S.M.; Liu, H.; Zhao, B.W.; Nie, C.H.; Wang, W.M.; Gao, Z.X. Construction of a high-density linkage map and fine mapping of QTLs for growth and gonad related traits in blunt snout bream. Sci. Rep. 2017, 7, 46509. [CrossRef] [PubMed]

57. Hu, Q.; Chang, C.; Wang, Q.; Tian, H.; Qiao, Z.; Wang, L.; Meng, Y.; Xu, C.; Xiao, H. Genome-wide RAD sequencing to identify a sex-specific marker in Chinese giant salamander Andrias davidianus. BMC Genom. 2019, 20, 415. [CrossRef] [PubMed]

58. Lee, B.Y.; Kim, M.S.; Choi, B.S.; Nagano, A.J.; Au, D.W.T.; Wu, R.S.S.; Takehana, Y.; Lee, J.S. Construction of high-resolution RAD-seq based linkage map, anchoring reference genome, and QTL mapping of the sex chromosome in the marine medaka. Oryzias Melastigma G3 2019, 9, 3537-3545. [CrossRef] [PubMed]

59. Liu, C.; Chen, H.; Ren, Z.; Zhang, C.; Yang, X. Population genetic analysis of the domestic Bactrian camel in China by RAD-seq. Ecol. Evol. 2019, 9, 11232-11242. [CrossRef]

60. Ren, A.; Du, K.; Jia, X.; Yang, R.; Wang, J.; Chen, S.Y.; Lai, S.J. Genetic diversity and population structure of four Chinese rabbit breeds. PLOS ONE 2019, 14, e0222503. [CrossRef]

61. Haqani, M.I.; Kawamura, K.; Takenouchi, A.; Kabir, M.H.; Nakamura, Y.; Ishikawa, A.; Tsudzuki, M. Growth performance and nonlinear growth curve functions of Large- and Normal-sized Japanese quail (Coturnix japonica). J. Poult. Sci. 2021, 58, 88-96. [CrossRef]

62. Science Council of Japan Guidelines for Proper Conduct of Animal Experiments. 2006. Available online: http:/ /www.scj.go.jp/ ja/info/kohyo/pdf/kohyo-20-k16-2e.pdf (accessed on 24 February 2020).

63. Kabir, M.H.; Takenouchi, A.; Haqani, M.I.; Nakamura, Y.; Takeuchi, S.; Tsudzuki, M. Discovery of a new nucleotide substitution in the MC1R gene and haplotype distribution in native and non-Japanese chicken breeds. Anim. Genet. 2020, 51, 235-248. [CrossRef] [PubMed]

64. Dvořák, P.; Doležalová, J.; Suchý, P. Photocolorimetric determination of yolk colour in relation to selected quality parameters of eggs. J. Sci. Food Agric. 2009, 89, 1886-1889. [CrossRef]

65. Bovšková, H.; Míková, K.; Panovská, Z. Evaluation of egg yolk colour. Czech. J. Food Sci. 2014, 32, 213-217. [CrossRef]

66. Sakaguchi, S.; Sugino, T.; Tsumura, Y.; Ito, M.; Crisp, M.D.; Bowman, D.M.J.S.; Nagano, A.J.; Honjo, M.N.; Yasugi, M.; Kudoh, H.; et al. High-throughput linkage mapping of Australian white cypress pine (Callitris glaucophylla) and map transferability to related species. Tree Genet. Genomes 2015, 11, 121. [CrossRef]

67. Langmead, B.; Salzberg, S.L. Fast gapped-read alignment with Bowtie 2. Nat. Methods 2012, 9, 357-359. [CrossRef] [PubMed]

68. Li, H.; Handsaker, B.; Wysoker, A.; Fennell, T.; Ruan, J.; Homer, N.; Marth, G.; Abecasis, G.; Durbin, R. The Sequence Alignment/Map format and SAMtools. Bioinformatics 2009, 25, 2078-2079. [CrossRef] [PubMed]

69. Koboldt, D.C.; Zhang, Q.; Larson, D.E.; Shen, D.; McLellan, M.D.; Lin, L.; Miller, C.A.; Mardis, E.R.; Ding, L.; Wilson, R.K. VarScan 2: Somatic mutation and copy number alteration discovery in cancer by exome sequencing. Genome Res. 2012, 22, 568-576. [CrossRef]

70. Li, H. A statistical framework for SNP calling, mutation discovery, association mapping and population genetical parameter estimation from sequencing data. Bioinformatics 2011, 27, 2987-2993. [CrossRef]

71. Danecek, P.; Auton, A.; Abecasis, G.; Albers, C.A.; Banks, E.; DePristo, M.A.; Handsaker, R.E.; Lunter, G.; Marth, G.T.; Sherry, S.T.; et al. The variant call format and VCFtools. Bioinformatics 2011, 27, 2156-2158. [CrossRef]

72. Manly, K.F.; Cudmore, R.H.; Meer, J.M. Map Manager QTX, cross-platform software for genetic mapping. Mamm. Genome 2001, 12, 930-932. [CrossRef] [PubMed]

73. Kosambi, D.D. The Estimation of map distances from recombination values. Ann. Hum. Genet. 1943, 12, 172-175. [CrossRef]

74. Broman, K.W.; Wu, H.; Sen, S.; Churchill, G.A. R/qtl: QTL mapping in experimental crosses. Bioinformatics 2003, 19, 889-890. [CrossRef]

75. Haley, C.S.; Knott, S.A. A simple regression method for mapping quantitative trait loci in line crosses using flanking markers. Heredity 1992, 69, 315-324. [CrossRef] [PubMed]

76. Broman, K.w.; Sen, S. A Guide to QTL Mapping with R/qtl; Springer: New York, NY, USA, 2009.

77. Broman, K.W.; Sen, S.; Owens, S.E.; Manichaikul, A.; Southard-Smith, E.M.; Churchill, G.A. The X chromosome in quantitative trait locus mapping. Genetics 2006, 74, 2151-2158. [CrossRef] [PubMed]

78. Darvasi, A.; Soller, M. A simple method to calculate resolving power and confidence interval of QTL map location. Behav. Genet. 1997, 27, 125-132. [CrossRef]

79. R Core Team. R: The R Project for Statistical Computing. Available online: https://www.r-project.org/ (accessed on 10 April 2020).

80. Morris, K.M.; Hindle, M.M.; Boitard, S.; Burt, D.W.; Danner, A.F.; Eory, L.; Forrest, H.L.; Gourichon, D.; Gros, J.; Hillier, L.W.; et al. The quail genome: Insights into social behaviour, seasonal biology and infectious disease response. BMC Biol. $2020,18,14$. [CrossRef]

81. Goraga, Z.S.; Nassar, M.K.; Brockmann, G.A. Quantitative trait loci segregating in crosses between New Hampshire and White Leghorn chicken lines: I. egg production traits. Anim. Genet. 2012, 43, 183-189. [CrossRef] [PubMed]

82. Liu, W.; Li, D.; Liu, J.; Chen, S.; Qu, L.; Zheng, J.; Xu, G.; Yang, N. A genome-wide SNP scan reveals novel loci for egg production and quality traits in White Leghorn and brown-egg dwarf layers. PLoS ONE 2011, 6, e28600. [CrossRef]

83. Tuiskula-Haavisto, M.; Honkatukia, M.; Preisinger, R.; Schmutz, M.; De Koning, D.J.; Wei, W.H.; Vilkki, J. Quantitative trait loci affecting eggshell traits in an $\mathrm{F}_{2}$ population. Anim. Genet. 2011, 42, 293-299. [CrossRef] [PubMed] 
84. Zhang, Y.; Hou, Z.C.; Chen, Z.X.; Zheng, J.X.; Chen, S.R.; Qu, L.J.; Li, J.Y.; Xu, G.Y.; Yang, N. Low-density lipoprotein receptorrelated protein 2 gene is associated with egg-quality traits in dwarf layers. Poult. Sci. 2011, 90, 2718-2722. [CrossRef] [PubMed]

85. Sun, C.; Lu, J.; Yi, G.; Yuan, J.; Duan, Z.; Qu, L.; Xu, G.; Wang, K.; Yang, N. Promising loci and genes for yolk and ovary weight in chickens revealed by a genome-wide association study. PLoS ONE 2015, 10, e0137145. [CrossRef]

86. Sasaki, O.; Odawara, S.; Takahashi, H.; Nirasawa, K.; Oyamada, Y.; Yamamoto, R.; Ishii, K.; Nagamine, Y.; Takeda, H.; Kobayashi, E.; et al. Genetic mapping of quantitative trait loci affecting body weight, egg character and egg production in $\mathrm{F}_{2}$ intercross chickens. Anim. Genet. 2004, 35, 188-194. [CrossRef] [PubMed]

87. Bhattacharya, T.K.; Chatterjee, R.N.; Sharma, R.P.; Rajkumar, U.; Niranjan, M.; Reddy, B.L.N. Association of polymorphism in the prolactin promoter and egg quality traits in laying hens. Br. Poult. Sci. 2011, 52, 551-557. [CrossRef] [PubMed]

88. Bhattacharya, T.K.; Chatterjee, R.N.; Sharma, R.P.; Niranjan, M.; Rajkumar, U. Associations between novel polymorphisms at the 5'-UTR region of the prolactin gene and egg production and quality in chickens. Theriogenology 2011, 75, 655-661. [CrossRef] [PubMed]

89. Yao, J.F.; Chen, Z.X.; Xu, G.Y.; Wang, X.L.; Ning, Z.H.; Zheng, J.X.; Qu, L.J.; Yang, N. Low-density lipoprotein receptor-related protein 8 gene association with egg traits in dwarf chickens. Poult. Sci. 2010, 89, 883-886. [CrossRef] [PubMed] 